\title{
El Derecho de Autodeterminación: un peligro para la paz en Europa \\ Javier Tajadura Tejada
}

Profesor Titular de Derecho Constitucional en la Universidad del País Vasco.

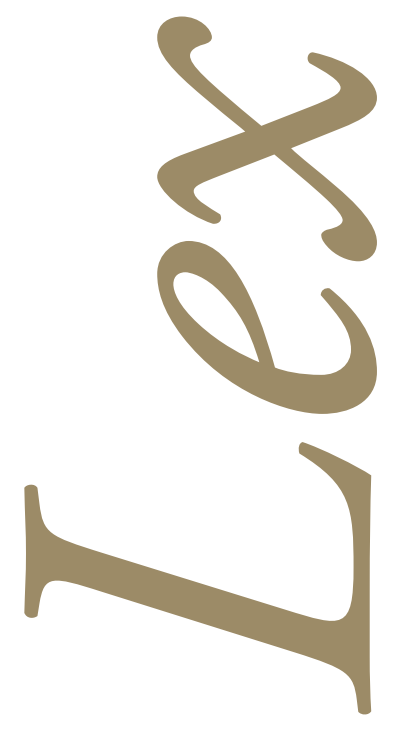




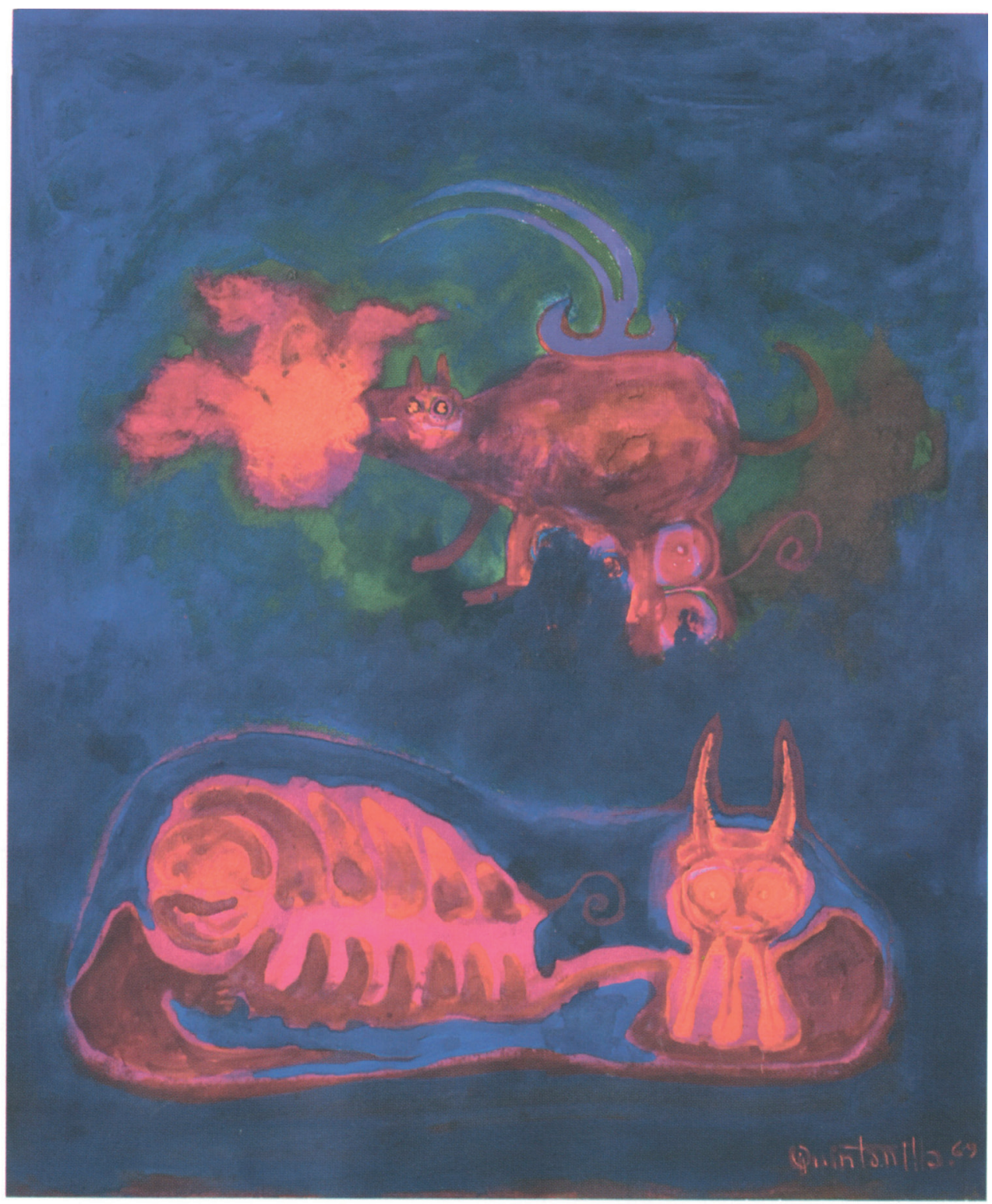

Ensayo. Técnica mixta, $1969(45 \mathrm{~cm}$. x $37.5 \mathrm{~cm}$.) 


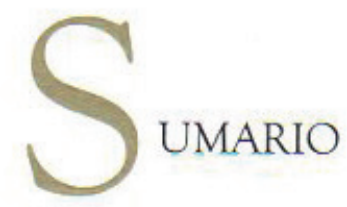

1. Introducción. 2. Derecho de Autodeterminación y Derecho Constitucional. 3. El Derecho de Autodeterminación en la teoria de la Constitución: pacto social y acto constitucional. 4. El Derecho de Autodeterminación en la praxis constitucional de España. 5. Derecho de Autodeterminación y Derecho Internacional. 6. Derecho de Autodeterminación y facticidad. 7. Derecho de Autodeterminación y nuevo proceso constituyente. 8. Derecho de Autodeterminación y Estado Federal. 9. La autodeterminación de Kosovo y las nuevas fronteras en Europa. 10. Conclusiones.

\section{INTRODUCCIÓN}

En febrero de 2008, Europa contempló el nacimiento de un nuevo Estado, Kosovo, que declaró unilateralmente su independencia respecto al Estado Serbio. En nuestro pais, el pasado día 28 de mayo, el Gobierno de la Comunidad Autónoma Vasca, presidido por el Sr. Ibarretxe aprobó un proyecto de ley para la celebración de un referéndum sobre el derecho de autodeterminación, cuyo ejercicio supondría la fragmentación territorial de España.

Aunque los analistas hayan subrayado, acertadamente, las diferencias existentes entre el Pais Vasco y Kosovo, lo cierto es que la problemática juridica subyacente es la misma: el significado y alcance del Derecho de Autodeterminación. Y que, lamentablemente, desde el punto de vista politico, ambos procesos están igualmente vinculados a fenómenos de terrorismo. En este contexto, el objeto de este capitulo es poner de manifiesto la necesidad de llevar a cabo un correcto entendimiento del derecho de autodeterminación, desde la perspectiva del Derecho Constitucional e Internacional, y ello por la sencilla razón de que de esa cabal comprensión depende, de una u otra suerte, la paz y la seguridad de Europa. Entender el derecho de autodeterminación como lo hacen los nacionalistas vascos o los separatistas kosovares, solo puede conducir a Europa al caos. En definitiva, es la consideración del derecho de autodeterminación 
como una amenaza para la paz y para la seguridad de Europa la que me ha llevado a redactar esta contribución.

Resulta oportuno subrayar también que en España, las reivindicaciones secesionistas aumentan de intensidad en función del contexto internacional. Asi, en 1990, fue la independencia de las Repúblicas bálticas, hasta entonces integrantes de la Unión Soviética, la que alentó a las fuerzas nacionalistas periféricas. Ese año, los Parlamentos del Pais Vasco y de Cataluña aprobaron sendas proposiciones no de Ley en las que manifestaban que no renunciaban al derecho de autodeterminación como meta. En los últimos tiempos, la creación del Estado independiente de Montenegro y la desmembración de Serbia provocada por la aludida independencia de Kosovo, se presentan como reconfortantes ejemplos para el nacionalismo catalán y vasco. Los resultados obtenidos por el Partido Nacionalista Escocés y la agónica situación del Estado belga, por citar dos supuestos que podrian poner en cuestión la integridad de Estados del Occidente europeo, parecen favorecer la lógica de la desintegración.

En este contexto, el objeto de estas páginas es poner de manifiesto que la inclusión en nuestro ordenamiento juridico-politico del derecho de autodeterminación -como derecho de secesión de una parte del pueblo español-, desde una perspectiva juridica y politica democrática, sólo sería posible mediante la apertura de un nuevo proceso constituyente. Doctrina esta que es extrapolable a cualquier otro Estado Constitucional. Para fundamentar con el debido rigor esta tesis, debemos, en primer lugar y aunque sea de forma breve, precisar el significado y alcance del derecho que nos ocupa (2). A continuación analizaremos la problemática del mencionado derecho, en la Teoria de la Constitución (3) y en la praxis constitucional española (4). Con esas premisas demostraremos que el derecho de secesión no encuentra encaje en nuestro ordenamiento ni como derecho humano ni bajo el paraguas del derecho internacional, que expresamente lo proscribe (5). En consecuencia, expondremos los peligros de aceptar su imposición por la via de los hechos (6) y défenderemos la apertura de un nuevo proceso constituyente como la única vía jurídica y política democrática para su reconocimiento (7). El capitulo incluirá también un examen de la relación entre Estado Federal y Derecho de Autodeterminación (8), y concluirá con el análisis del caso de Kosovo en la medida en que, se quiera o no, acabará convirtiéndose en un precedente a favor de cualquier proceso secesionista (9) bien sea en España o en cualquier otro lugar de Europa, donde el nacionalismo identitario haya arraigado con fuerza suficiente como para reivindicar la autodeterminación.

\section{DERECHO DE AUTODETERMINACIÓN Y DERECHO CONSTITUCIONAL}

El derecho de autodeterminación es un tema complejo y proteico, presenta una rica problemática en la que Derecho y Politica se funden, y por ello resulta sumamente escurridizo para el jurista. 
En la doctrina suele ser común distinguir entre el significado y alcance que dicho derecho presenta en el Derecho Público Interno y en el Derecho Internacional Público. Así, para el Derecho Público Interno, esto es para el Derecho Constitucional, el ejercicio del derecho de autodeterminación se identifica con el principio democrático, fundamento último del Estado Constitucional. Por otro lado, en el Derecho Internacional Público, la autodeterminación presenta cuatro posibles opciones o posibilidades que conviene recordar, dado que en el lenguaje político se suele prescindir de las tres primeras:

a) En primer lugar el derecho de autodeterminación puede traducirse en la libre asociación con un Estado independiente. Estados asociados al Reino Unido fueron en su momento, por ejemplo los Estados insulares de Dominica, Granada, Santa Lucia, San Vicente y Granadinas, Antigua y Bermudas. Todos ellos son hoy Estados independientes. En la actualidad, Puerto Rico conserva el status de Estado libre asociado a los Estados Unidos. En todo caso, conviene subrayar que los pueblos que adoptan esta decisión acaban optando bien por la independencia plena, bien por la total integración en el Estado al que inicialmente se asocian.

b) En segundo lugar, el derecho de autodeterminación puede concretarse en la integración de un Estado hasta entonces independiente en otro Estado soberano. Tal fue lo que ocurrió con los Estados de Vermont y Tejas en 1791 y 1845, respectivamente, que se integraron en los EE.UU. o, más recientemente, de la República Democrática Alemana que en 1990 se integró en la República Federal de Alemania.

c) En tercer lugar puede referirse a la decisión de un Pueblo de un determinado territorio de continuar formando parte del Estado al que ya pertenece.

d) Finalmente, y en cuarto lugar, la autodeterminación se identifica también con la independencia o secesión. Ese fue el caso de las Repúblicas Bálticas respecto de la Unión Soviética.

Ahora bien, como ha recordado el profesor Ruipérez, esta distinción entre el Derecho de Autodeterminación según el Derecho Interno y según el Derecho Internacional, es, en cierto modo, ficticia y, desde luego, puramente funcional. Se apoya exclusivamente en la diferente perspectiva desde la que se observa el ejercicio del derecho de autodeterminación (esto es, los ciudadanos o la Comunidad Internacional) y en si dicho ejercicio provoca, o no, variaciones de las fronteras interestatales, esto es, modificaciones en el mapa de Estados. Si el ejercicio del derecho de autodeterminación provoca el surgimiento de un nuevo Estado o la desaparición de uno anteriormente existente, dicha problemática se situará en el ámbito del Derecho Internacional. Por el contrario, si la autodeterminación conlleva el mantenimiento de una 
estructura estatal, aunque dotada de un nuevo Texto Constitucional y por tanto de una nueva organización politica, el supuesto es calificado como acto de Derecho Público Interno!.

Y decimos que se trata de una distinción relativa y meramente funcional, porque en ambos casos el derecho de autodeterminación es la materialización práctica del principio democrático. Razón esta que explica que sea la Teoría del Estado y el Derecho Constitucional, y no el Derecho Internacional Público, la que nos proporcione las claves fundamentales para la comprensión de la institución.

\section{EL DERECHO DE AUTODETERMINACIÓN EN LA TEORÍA DE LA CONSTI- TUCIÓN: PACTO SOCIAL Y ACTO CONSTITUCIONAL}

La teoria del pacto social sirve para explicar el significado y alcance del derecho de autodeterminación. Dicha doctrina está en la base de los procesos constituyentes que fundaron el constitucionalismo moderno, esto es el norteamericano y el francés. En esos procesos, como han puesto de relieve los profesores, De Vega y Ruipérez, se siguieron, de un modo u otro, los esquemas teóricos trazados, ya en 1717 , por el reverendo John Wyse, de forma que en ellos pueden fácilmente distinguirse tres etapas diferenciadas y sucesivas: declaración de derechos, pacto social y acto constitucional.

Analicemos brevemente cada una de ellas. Por lo que se refiere a la primera etapa, resulta incuestionable el hecho de que la primera preocupación de los revolucionarios liberal-burgueses, tanto en Francia como en América, fue la de proceder al reconocimiento de la existencia de una esfera de libertad individual absoluta. Esa preocupación se tradujo en el plano normativo en las declaraciones de derechos fundamentales. Será en un momento posterior cuando se proceda a aprobar la Constitución y esto último se hará siempre, precisamente, para garantizar aquellos derechos mediante la separación de poderes. En cualquier caso, lo que importa subrayar es que las declaraciones de derechos se configuran como un presupuesto inexcusable para la existencia misma del Estado Constitucional y que lo distinguen del Estado absoluto. Frente a las concepciones absolutistas según las cuales los privilegios son concesiones graciosas de los monarcas a las clases sociales más poderosas, se impone la tesis, tributaria de las doctrinas iusnaturalistas, de que todo hombre por el hecho de serlo es titular de unos derechos preexistentes al Estado y que, por tanto, deben ser por él respetados.

1 Rutperez, Javier (2003). Proceso Constituyente, Soberania y Autodeterminación. Madrid: Biblioteca Nueva, p. 296. Sobre el significado y alcance del derecho de autodeterminación desde una perspectiva constitucional, resulta imprescindible, del mismo autor: Ruipérez, Javier (1995). Constitución y Autodeterminación. Madrid: Tecnos. 
La tercera etapa (dejemos de lado por el momento la segunda) es también fácilmente identificable en los procesos revolucionarios americano y francés. Una vez que, mediante la declaración de derechos, se ha establecido la esfera de libertad individual, de lo que se trata es de hacerla efectiva. En ello consiste el acto constitucional, en aprobar un Texto constitucional que organizando el Estado conforme al principio de división de poderes asegure al ciudadano el respeto a su ámbito de libertad personal. Evidente resulta que este acto constitucional concebido como supremo sistema de garantia de la libertad individual requiere, por ineludible exigencia del racionalismo jurídico, su plasmación en un documento escrito, formal y solemne, aprobado por el Pueblo, titular del Poder Constituyente.

El segundo momento o etapa del proceso constitucional según el aludido esquema del reverendo Wyse, el pacto social, resulta más dificil de identificar en la práctica, y ello porque se verifica al mismo tiempo que el acto constitucional. Sin embargo, a pesar de esa simultaneidad en el tiempo, lo cierto es que desde un punto de vista conceptual o teórico el pacto social es un momento clara y necesariamente diferenciado tanto de la declaración de derechos como del acto constitucional.

Probablemente debamos a Isnard una de las más precisas formulaciones de tan importante distinción. Reproduzco la cita que, aunque larga, considero imprescindible por la claridad que aporta sobre este tema: "Debe reconocerse en primer lugar (...) cuáles son los derechos naturales de todos y proclamarlos (...) Para seguir el orden natural de la organización social hay que proceder, antes de toda ley constitucional, a la redacción de un pacto social. Este acto debe ser intermedio entre la declaración de derechos, que le sirve de base, y la Constitución, a la que sirve de barrera y regulador. Si el pacto social difiere de una simple declaración de derechos, difiere más aún de un acto constitucional. Hacer un pacto social es redactar el instrumento por el que ciertas personas consienten formar una asociación con tales o cuales condiciones previas. Hacer una Constitución, por el contrario, es únicamente determinar la forma de gobierno (...) En un caso se crea la sociedad, en el otro se organiza"2.

La relevancia de esta última distinción en relación con la aplicación del principio democrático no puede ser soslayada: "En un caso se crea la sociedad, en el otro se organiza" (Isnard). Y ello porque va a ser mediante el pacto social como surja el Poder Constituyente y como se configure, por tanto, el titular de la soberania. Desde un punto de vista lógico resulta incuestionable que si la Constitución es el fruto de la voluntad del poder constituyente, el surgimiento de este último debe ser previo a aquella. Mediante la verificación del pacto social, el Pueblo

2 Isnard, Archives Parlamentaires, vol. LXIV, p. 417. Tomo la cita de De Vega, Pedro: "Mundialización y Derecho Constitucional: la crisis del principio democrático en el constitucionalismo actual", Revista de Estudios Politicos, No 100,1998 , p. 28. 
queda afirmado como el único sujeto titular de la soberanía en el Estado. A partir de entonces, el Pueblo puede en virtud de su condición de soberano imponer su voluntad a los ciudadanos individualmente considerados, y por tanto, está facultado para aprobar, establecer y sancionar la Constitución.

Fácilmente se comprende a la luz de todo lo anterior que el constitucionalismo moderno sea considerado como un movimiento tributario de las tesis contractualistas o pactistas, y de manera fundamental de las construcciones de Althusius, Hobbes o Rousseau, y que toda Constitución se configure hoy dia como un pacto. Ahora bien, el problema surge al determinar cuál es la naturaleza de ese pacto. Porque algunos de los defensores del derecho de autodeterminación como ius secessionis lo identifican con el antiguo pacto feudal, lo cual resulta, desde la lógica del Estado Constitucional, inadmisible.

El pacto social no es un contrato asimilable a los que operan en el tráfico juridico privado, esto es, en el ámbito del Derecho Civil. Antes al contrario, el pacto social debe ser entendido como una hipótesis de derecho puro. Hipótesis que tiene por objeto o finalidad explicar la situación reciproca de los ciudadanos de un Estado libre. El carácter hipotético del pacto social lo puso de manifiesto su más celebre formulador. En El Contrato Social Rousseau advertia lo siguiente: "las cláusulas de este contrato se hallan determinadas hasta tal punto por la naturaleza del acto, que la menor modificación las haría vanas y de efecto nulo; de suerte que, aun cuando jamás hubiesen podido ser formalmente enunciadas, son en todas partes las mismas, y doquiera están tácitamente admitidas y reconocidas" 3 .

En este sentido creo oportuno reproducir la definición que del pacto -como hipótesis de derecho puro- ofrece Rousseau, en la medida en que según la tesis que defiendo en este ensayo, dicho contrato social se identifica con el ejercicio del derecho de autodeterminación: "Si se elimina del pacto social lo que no le es de esencia, nos encontramos con que se reduce a los términos siguientes: 'Cada uno de nosotros pone en común su persona y todo su poder bajo la suprema dirección de la voluntad general, y nosotros recibimos además a cada miembro como parte indivisible del todo'. Este acto produce inmediatamente, en vez de la persona particular de cada contratante, un cuerpo moral y colectivo, compuesto de tantos miembros como votos tiene la asamblea, el cual recibe de este mismo acto su unidad, su yo común, su vida y su voluntad". Como nos recordó el maestro Tuñón de Lara, el gran tema del Contrato Social no es otro que "la fundamentación de la legitimidad democrática (...) El pacto social de Rousseau no es, ni ha pretendido ser nunca, una hipótesis histórica: es una fundamentación teórica"4.

3 Rousseau, J.J.: Contrato social (1762), Traducción de Fernando de los Rios y prólogo de M. Tunón de Lara (5a ed, 1990). Madrid, Espasa-Calpe, p. 48.

4 MuÑón de Lara, Manuel. "Prólogo" a Contrato Social... op. cit. p. 12. 
Según Rousseau, y tal y como había afirmado antes Grocio, "un pueblo es un pueblo antes de darse un rey". Y, trasladando la idea a nuestro tiempo, podemos decir que un pueblo es un pueblo antes de dotarse de una Constitución. Dicho con otras palabras, el surgimiento del Poder Constituyente precede lógica e históricamente a la aprobación de la Constitución. Y dicho surgimiento en virtud de un pacto social entendido como hipótesis teórica para fundamentar la legitimidad democrática, es el que nosotros identificamos con el ejercicio del derecho de autodeterminación.

Por todo lo anterior entiendo que se puede afirmar, que el derecho de autodeterminación se ejercita mediante la realización del Pacto Social ${ }^{5}$, por el que se crea el Poder Constituyente. Ahora bien, cada vez que entra en escena un nuevo Constituyente, las posibilidades que se le ofrecen son básicamente tres. Esto es, el ejercicio del derecho de autodeterminación puede conducir a uno de estos tres escenarios ${ }^{6}$ :

a) En primer lugar, la creación de una nueva comunidad politica. El Pacto Social reviste en estos supuestos un indiscutible carácter fundacional. Eso fue lo que ocurrió con la reunión de la Convención de Filadelfia que el 25 de mayo de 1787 dio origen al nacimiento de los Estados Unidos de América, como Estado Constitucional en su manifestación estructural de Estado Federal. Y es también la hipótesis que habrá de verificarse en Europa para que el proceso de integración continental actualmente articulado mediante una Confederación de Estados en su forma moderna, desemboque en la creación de un Estado Constitucional.

b) En segundo lugar, el pacto social puede verificarse en el seno de comunidades políticas ya existentes en aquellos casos en que estas desean dotarse de una nueva forma de organización o, utilizando la categoría del maestro Lucas Verdú, modificar su fórmula política. Nos encontramos de este modo, ante un acto que si bien no tiene un carácter fúndacional, si al menos debe reconocérsele el de acto refundacional. Esto fue lo que sucedió en la Francia de 1789-1791 que rompió con el Antiguo Régimen y, después, en 1792-1793, en que se renunció al marco constitucional de 1791. Por lo que se refiere a nuestro pais, esto fue también lo que sucedió en 1812 , $1869,1873,1931$, y sobre todo y como veremos después, en 1977-78.

5 Como advierte De Miguel Bárcena, se comprende asi el verdadero significado de la autodeterminación como derecho humano: "el derecho de autodeterminación es un derecho humano, pero sólo en la medida en que se ejerce bajo los auspicios de la teoria racional del poder constituyente, esto es, el individuo soberano, que a través del principio de autonomía que proporciona el imperativo categórico kantiano, cede su soberania a una entidad superior, el pueblo, en las condiciones limitativas impuestas por el pacto social y un texto constitucional de carácter rigido encargado de salvaguardar el principio democrático....." De Miguel Bárcena, José (2006) "Variaciones contemporáneas del derecho de autodeterminación: El derecho a decidir y la propuesta de reforma del Estatuto de Autonomia del País Vasco", Anuario da Facultade de Dereito da Universidade da Coruña, núm. 10, p. 265.

6 Ruirérez, Javier (2003). "Proceso Constituyente, Soberania" op. cit. p. $301-303$. 
c) En tercer lugar, el pacto social puede dar lugar a la disolución de la propia comunidad politica. Tal fue el caso, relativamente reciente, que se dio en la última década del siglo pasado en la antigua República de Checoeslovaquia. Tras la caida del régimen comunista se abrió en aquél pais un proceso constituyente, proceso que hubiera podido concluir con la decisión de continuar conservando una estructura estatal única vertebrada en torno a valores y principios diferentes. Sin embargo, como es bien sabido, no fue esa la decisión del Poder Constituyente ya que este optó por proceder a la disolución del Pacto Social del 28 de octubre de $1918^{7}$, y con él, a la escisión de la antigua República en dos nuevas, la República checa y la República eslovaca, cada una de las cuales, en ejercicio de su soberanía, se dotaría de su propia Constitución.

\section{EL DERECHO DE AUTODETERMINACIÓN EN LA PRAXIS CONSTITUCIO. NAL DE ESPAÑA}

Con las anteriores premisas, estamos ya en condiciones de analizar la problemática de la autodeterminación en el concreto ordenamiento constitucional español. En este sentido, lo primero que debemos hacer es examinar el modo en que los españoles ejercimos el derecho de autodeterminación.

Establecida la necesidad desde un punto de vista lógico e histórico de distinguir en todo proceso constituyente el momento del pacto social y el momento del acto constitucional, procede identificar ahora ambos episodios en el camino que culminó con la aprobación de la Constitución de 1978. Y si por lo que se refiere al segundo de ellos, resulta pacifico afirmar que puede datarse en diciembre de 1978, no ocurre lo mismo en relación al momento en que tuvo lugar el pacto social -reitero una vez más, pacto como hipótesis de derecho puro y no como pacto feudal dentro de la lógica del principio monárquico.

Efectivamente, es preciso reconocer que determinar en qué momento los españoles adoptamos la decisión politica fundamental de continuar unidos en una única estructura estatal pero con una fórmula política no solo diferente sino completamente antagónica a la vigente durante el régimen del dictador Franco, no es tarea fácil. Ahora bien, el hecho de que sea dificil de fijar en el tiempo el momento exacto en que se verificó el pacto social, no quiere decir en modo alguno que dicho pacto no hubiera tenido lugar. Como hemos visto, sin el Pacto, no hubiera podido surgir Poder Constituyente alguno y la Constitución de 1978 se veria privada de su fundamento y legitimidad democrática.

7 El 28 de octubre de 1918, la Comisión Nacional aprobó la Ley de Recepción. La aprobación de la misma reviste según la doctrina el carácter de acto fundacional de la antigua Checoslovaquia como Estado independiente. Dicho Pacto Social fue ratificado en diversas ocasiones hasta que en los años 90 del siglo pasado fue sustituido por dos nuevos y privativos pactos sociales. 
Así las cosas, aunque considero muy aventurado identificar el momento del pacto social con un episodio histórico determinado, creo absolutamente imprescindible subrayar que dicho pacto tuvo lugar y ello en la medida en que desde formaciones politicas nacionalistas se pretende negar tal evidencia.

Si bien es verdad que los españoles no protagonizamos una escena como la celebérrima reunión de la Convención de Filadelfia en la que se culminó de forma clara el proceso altusiano de traslación de la soberanía desde los individuos aisladamente considerados al Pueblo del Estado como unidad política diferenciada, lo cierto es que entre 1976 y 1978 se sucedieron distintos episodios en los que cabe entender que el pacto social tuvo lugar. Entre ellos cabe señalar los siguientes: el referéndum de aprobación de la Ley para la Reforma Política de 1976, la campaña electoral de junio de 1977, o el acto de votación de las elecciones de 15 de junio de 1977.

Cuando las Cortes elegidas aquel histórico 15 de junio, se autoproclamaron como constituyentes, obraron del mismo modo que los Estados Generales en la Francia de 1789 o las Cortes de Cádiz, esto es, rompiendo todo nexo de unión con la situación juridica y politica precedente. La voluntad del pueblo español a favor del mantenimiento de España como una estructura estatal única vertebrada en torno a los principios y valores del constitucionalismo democrático y social resulta incuestionable. Esa voluntad popular se expresó tanto de manera indirecta, según los esquemas propios de la democracia representativa, a través de los miembros de la Constituyente, como directa, en el referéndum del 6 de diciembre de 1978.

La conclusión que debemos extraer de estos datos en orden a nuestro tema no puede resultar más clara: los españoles hemos ejercido ya el derecho de autodeterminación. Esta tesis fue defendida, en sede política, por uno de los grandes protagonistas y artifices de nuestra régimen constitucional y hoy Presidente de la Comisión Constitucional del Congreso, Alfonso Guerra. Cuando en 1989 y 1990 algunas formaciones políticas nacionalistas reclamaron el derecho de autodeterminación, el entonces Vicepresidente del Gobierno les respondió quẹ su pretensión era absurda e inconsistente, toda vez que el pueblo español ya se habia autodeterminado con la aprobación de la Constitución.

Ello es lo que explica que la Constitución haya sido definida como el gran pacto social y político para la convivencia de los españoles. En este sentido, mi maestro, el profesor Torres del Moral ha escrito: "Si toda Constitución normativa y democrática es, y no puede dejar de ser, un gran pacto entre las fuerzas que están en tensión dialéctica acerca de las reglas del juego social, político y económico, la Constitución española lo es plenamente, incluso (...) por el método seguido durante el proceso constituyente. Este pacto juega un papel importantísimo de integración de dichas fuerzas, así como de los diversos territorios, en el régimen instaurado" 8 .

8 Torres del. Moral, Antonio (2004). Principios de Derecho Constitucional español. Tomo I. Sistema de fuentes. Sistema 
En España, por tanto, se ha dado sobrado cumplimiento al derecho de autodeterminación. Es más, siguiendo a Ruipérez, podríamos afirmar que el ejercicio de este derecho se ha verificado con un doble giro de tuerca.

Como advirtió Kelsen, en todo Estado Federal, o si se quiere políticamente descentralizado, la población (como también el territorio) es objeto de una doble cualificación: por un lado, los individuos son ciudadanos de la Federación y por otra en tanto que habitantes de cada una de las colectividades miembros tienen reconocida también la ciudadania del Estado particular de que se trate. Ambas ciudadanias están en estrecha e intima conexión habida cuenta que el Derecho Constitucional federal comparado nos muestra cómo la adquisición de una conlleva necesariamente la de la otra ${ }^{9}$. El esquema es, en opinión del profesor Ruipérez que comparto plenamente, aplicable al caso español donde cabe hablar del Pueblo como pueblo federal o estatal y como pueblo de cada una de las comunidades autónomas (terminologia esta adoptada por los distintos Estatutos de Autonomia integrantes de nuestra Constitución territorial).

$\mathrm{Si}$, como hemos expuesto anteriormente ninguna duda cabe de que el pueblo, como pueblo estatal en su conjunto, ejerció el derecho de autodeterminación, procede examinar lo que ocurrió respecto a esa otra cualificación del pueblo como pueblo de cada una de las colectividades miembros. De esta forma comprenderemos la anterior afirmación relativa a que en España la autodeterminación ha sido ejercida con un doble giro de tuerca.

También desde esta segunda perspectiva se ha dado satisfacción al derecho que nos ocupa. Tal es el significado que debemos atribuir a la aprobación de todos y cada uno de los Estatutos de Autonomia con los que se concreta el marco de distribución territorial del poder. Significado que se acentúa en el caso de las comunidades que en el pasado habian plebiscitado sus Estatutos (Cataluña, Pais Vasco y Galicia) así como Andalucia. Si en las comunidades que accedieron a la autonomía por la vía del artículo 143, la aprobación de su norma fundacional es obra exclusivamente de sus representantes, no ocurre lo mismo en las configuradas según los requerimientos del artículo 151.2, por la sencilla razón de que en estos supuestos el texto aprobado por los representantes obligatoriamente ha de ser sometido "a referendum del cuerpo electoral de las provincias comprendidas en el ámbito territorial del proyectado Estatuto".

de los derechos. Madrid: Servicio de Publicaciones de la Facultad de Derecho de la Universidad Complutense 5a edición, p. 96.

9 Kelsen, Hans (1925). Teoria General del Estado. Granada: Comares (?), Granada, p. 360: "Entre las dos ciudadanias existentes en el Estado federal -la de la Unión y la del Estado miembro- tiene que haber necesariamente una cierta conexión. Seria posible que la adquisición y la pérdida de las mismas estuviesen reguladas con entera independencia (...) Pero la regla general es la existencia de alguna conexión entre ellas; de ordinario, la adquisición de ciudadania en un Estado miembro tiene por consecuencia la adquisición de la ciudadania federal". 
De lo expuesto hasta ahora se deduce con claridad que el significado y alcance del Derecho de Autodeterminación en el Estado Constitucional español nada tiene que ver con la interpretación que del mismo hace el presidente de Gobierno Vasco. Para él, de lo que se trata es de que, en octubre de 2008, los ciudadanos vascos se pronuncien sobre si quieren o no introducir el derecho de autodeterminación -como derecho de secesión- en el ordenamiento juridico español. La legitimidad y legalidad de un tal referéndum es algo que da por supuesto. Y sin embargo, tal entendimiento del derecho de autodeterminación, eufemísticamente denominada en las propuestas del Sr. Ibarretxe, "derecho a decidir", resulta ilegítima, ilegal, y antidemocrática.

La ilegalidad de una tal consulta es manifiesta puesto que, en nuestro ordenamiento, los referendos sólo pueden ser convocados por el Rey, mediante propuesta del Presidente del Gobierno previa autorización del Congreso de los Diputados. (art. $92 \mathrm{CE}$ ). Por otro lado, el articulo 149.1.32 CE establece como competencia exclusiva de los poderes centrales del Estado, "la autorización para la convocatoria de consultas populares por via de referéndum". El único referéndum que puede convocar el lehendakari es el relativo a un Estatuto de Autonomía aprobado por las Cortes Generales (art. $151 \mathrm{CE}$ ). Para que pudiera legítimamente convocar otro tipo de consultas sería preciso que el Estado transfiriese o delegase dicha competencia mediante una Ley Orgánica de las previstas en el articulo 150.2 CE.

Ahora bien, si el procedimiento de la consulta como tal es manifiestamente ilegal, todavía lo es más su objeto. Juridicamente, el derecho de autodeterminación no puede ser introducido en el ordenamiento mediante una reforma del Estatuto como pretendió Ibarretxe en su Plan, ni mediante un pacto o acuerdo con el Presidente del Gobierno como pretende ahora, ni siquiera, mediante una reforma de la Constitución española. La reforma constitucional como facultad constitucional y por ello limitada, formalmente y materialmente, por el propio texto constitucional, encontraria un limite infranqueable en la titularidad de la soberania, única e indivisible, por parte del pueblo español. Este límite impediria incluir mediante la reforma de la Constitución el derecho de autodeterminación de una fracción del pueblo del Estado, en la medida en que dicha posibilidad fue expresamente excluida por la Constituyente de 1978. Salvo que se pretenda realizar un ejercicio de falsificación de la realidad y de la historia, es preciso reconocer que la problemática de la autodeterminación no fue eludida sino que fue abordada expresamente. Las enmiendas que en sede constituyente se presentaron a favor del reconocimiento del ius secessionis fueron todas rechazadas de forma rotunda y contundente. Es precisamente ese rechazo expreso del derecho de autodeterminación como ius secessionis por parte del Constituyente de 1978 el que convierte en inadmisibles desde una perspectiva juridico-constitucional, (al margen de su legitimidad politica o ideológica) las pretensiones de los juristas y los políticos que se han adherido a las tesis del nacionalismo soberanista, de fundar tal derecho en el Texto Constitucional bien sea como derecho internacional, como derecho humano, o como derecho histórico. Se trata de tesis que pretenden deducir de la Constitución lo que esta expresamente 
rechaza, y que, en la medida en que pretenden atribuir a una fracción del pueblo del Estado el derecho a decidir en nombre de la totalidad del pueblo, se oponen al principio democrático básico de que lo que a todos concierne por todos debe ser decidido.

\section{DERECHO DE AUTODETERMINACIÓN Y DERECHO INTERNACIONAL}

El nacionalismo vasco, para justificar o fundamentar juridicamente sus propuestas, suele acudir al derecho Internacional y a los derechos humanos, dejando como afirmación retórica la referencia a los derechos históricos. Los defensores de las propuestas soberanistas sostienen que el derecho de autodeterminación como derecho de secesión es un derecho reconocido por Tratados Internacionales ratificados por España; además, dicho derecho -al amparo del art. 10. 2 CE- estaria vigente en nuestro ordenamiento en la medida en que se trata de derecho humano.

Es ciertamente llamativo que el nacionalismo vasco apele al Derecho Internacional para justificar el derecho de autodeterminación del pueblo vasco. Y esto es algo que debe ser subrayado pues implica un cambio notable en su estrategia politica. Hasta ese momento, el nacionalismo vasco pretendia justificar sus aspiraciones independentistas y reformistas, apelando a los derechos históricos. Pero, ciertamente, era una empresa harto complicada intentar fundamentar la secesión exclusivamente en un titulo histórico, difícilmente compatible, además con el principio democrático. Al fin y al cabo, como ha señalado el profesor Solozábal, "los derechos históricos no denotan, ni pueden hacerlo, un poder originario, de justificación extraconstitucional, sencillamente porque ello choca lógicamente con la idea irrenunciable de Constitución en cuanto decisión total e incondicionada, verdaderamente fundante, de la vida política de la comunidad"10.

Asi, el Preámbulo de la Propuesta de nuevo estatuto (Plan Ibarrtexe), tras una breve digresión en torno al sujeto político que lo fundamenta, aparecia el siguiente párrafo: "El pueblo vasco tiene derecho a decidir sobre su propio futuro, tal y como se aprobó por mayoría absoluta el 15 de febrero de 1990 en el Parlamento Vasco, y de conformidad con el derecho de autodeterminación de los pueblos, reconocido internacionalmente, entre otros, en el Pacto Internacional de Derechos Civiles y Politicos y en el Pacto Internacional de Derechos Económicos, Sociales y Culturales".

El cambio estratégico del nacionalismo básico persigue dos objetivos. El primero de carácter politico, internacionalizar el hipotético contencioso vasco, tratando de presentarlo ante la opinión pública mundial como un problema aparentemente colonial. Aunque esto carezca de propuesta politica para la convivencia politica del Lehendakari Ibarretxe, OñateI: IVAP, p. 384. 
cualquier fundamento, preciso es reconocer que en determinados contextos y escenarios podría encontrar algún tipo de apoyo. El segundo, de carácter técnico-jurídico, recurrir a un instrumento legal cuya inserción en nuestro ordenamiento se afirma para legitimar la secesión.

Si nos situamos en el plano del Derecho Internacional, y -con total independencia de lo que el derecho interno prevea sobre la cuestión- examinamos si en la realidad social y política de España concurren o no las circunstancias que legitiman y hacen licita la autodeterminación desde la mencionada perspectiva juridica internacional, fácilmente comprenderemos que la respuesta sea negativa.

El derecho de autodeterminación cumple en el Derecho Internacional y en el desarrollo progresivo de la sociedad internacional una función histórica concreta: llevar a cabo la descolonización, esto es, permitir a los pueblos coloniales acceder a su independencia. Por ello la Resolución de Naciones Unidas 1514 (XV), que es la que otorga cobertura juridica al derecho de autodeterminación en el plano internacional, ha sido acertadamente denominada como carta magna de la descolonización. La Resolución 1514 apunta con claridad al marco en que se circunscribe el derecho que analizamos, pues se trata de la "Declaración sobre la concesión de la independencia a los paises y pueblos coloniales". Esta Resolución afirmó por primera vez que el fenómeno colonial es contrario a la Carta de Naciones Unidas, concretando además el contenido del derecho a la libre determinación de los pueblos en términos prácticamente iguales a los que seis años más tarde establecerian los Pactos Internacionales de 1966 ": "1. "La sujeción de pueblos a subyugación, dominación y explotación extranjeras constituye una denegación de los derechos humanos fundamentales, es contraria a la Carta de Naciones Unidas y compromete la causa de la paz y de la cooperación mundiales. 2. Todos los pueblos tienen el derecho de libre determinación, en virtud de ese derecho, determinan libremente su condición política y persiguen libremente su desarrollo económico, social y cultural".

Aunque la referencia a todos los pueblos pueda parecer muy amplia, hoy es mayoritariamente aceptado por la doctrina internacionalista que los destinatarios del derecho no son todos los pueblos sino, por una parte, aquellos que se encuentran sometidos a dominación colonial, extranjera o racista y, por otra, aquellos que no encontrándose en alguna de estas situaciones forman parte de un Estado ya constituido que no esté dotado "de un gobierno que represente a la totalidad del pueblo perteneciente al territorio, sin distinción por motivos de raza, credo o color". Este último caso, estaria ligado a uno de los aspectos de mayor relevancia del principio democrático, en virtud

1 El art. 1 común de los Pactos Internacionales de Derechos Civiles y Políticos y de Derechos Económicos, Sociales y Culturales, de 16 de diciembre de 1966, afirmaba que "todos los pueblos tienen el derecho a la libre determinación", en virtud del cual "establecen libremente su condición política y proveen asimismo a su desarrollo económico, social y cultural”. 
del cual la denegación del derecho a participar en la vida pública, impidiendo a los miembros de ese pueblo el acceso real al gobierno para el desarrollo politico, económico o cultural, tendría como consecuencia, de forma excepcional, el derecho a la libre determinación de ese pueblo. Esta cláusula es conocida como "cláusula de salvaguardia", y ha sido interpretada por determinados sectores de la doctrina internacionalista como vía legítima para la secesión.

Sin embargo, y como bien advierte Josu de Miguel, los que defienden la legitimidad internacional de la secesión, olvidan que la cláusula de salvaguardia fue concebida en pleno movimiento descolonizador con un objeto muy definido: presionar a los nuevos Estados surgidos en el curso del mismo para que respetaran los derechos de muchos pueblos que quedaran divididos por las fronteras establecidas artificialmente por las potencias coloniales, y que de esa forma se habian convertido en una minoria frente a otro grupo étnico que ostentaba el poder en el momento del acceso a la independencia. ${ }^{12}$.

Por lo demás, no existe apoyo alguno en el Derecho Internacional para aplicar ese derecho a situaciones no coloniales. En este sentido, la Resolución 2625 (XXV) de Naciones Unidas precisa que, ninguna de las disposiciones incluidas bajo el principio de igualdad de derechos y de la libre determinación de los pueblos se entenderá en el sentido de que autorice o propicie acción alguna encaminada a quebrantar o menoscabar, total o parcialmente, la integridad territorial de Estados soberanos e independientes que se conduzcan de acuerdo con el principio en cuestión "y estén, por tanto, dotados de un gobierno que represente a la totalidad del pueblo perteneciente al territorio sin distinción por motivos de raza, credo o color". De ello se deduce también, con claridad, que, solo cabe reconocer el derecho de autodeterminación a favor de pueblos incluidos en Estados carentes de instituciones democráticas.

En el Derecho Internacional vigente, todo intento de destruir parcial o totalmente la unidad nacional y la integridad territorial de un pais es incompatible con los fines y los principios de la Carta, que son también los de los Estados existentes. En conclusión, debe afirmarse que el Derecho Internacional no reconoce el derecho de secesión, entendido este como el derecho de un pueblo que forma parte de un Estado ya constituido a escindirse o separarse de este.

En definitiva, considero innecesario detenerme a justificar lo obvio, esto es, que en España no hay pueblos coloniales y que se trata de un Estado dotado de instituciones democráticas. Ninguno de los supuestos que justifican la secesión se da en España. Y en la medida en que no se dan, el Derecho Internacional garantiza la unidad y la continuidad del Estado Constitucional español como miembro de la Comunidad Internacional, consagra su integridad territorial y prohibe atentar contra ella. Por tanto, no es solo que el derecho de autodeterminación como

12 De Miguel BarcenA, Josu (2006). “Variaciones contemporáneas...” Op. cit. p. 269. 
ius secesionis, tal y como se plantea en las sucesivas propuestas de Ibarrtexe, no tenga cabida ni encaje en el Derecho Internacional sino que además se encuentra en él proscrito.

Descartada la posibilidad de fundamentar el ius secessionis en el Derecho Internacional General, en la medida en que España es un Estado dotado de instituciones democráticas y en el que no existen ni pueblos coloniales ni pueblos perseguidos, se ha pretendido deducir el derecho de autodeterminación del artículo 10. 2 CE, como un derecho humano aplicable en nuestro ordenamiento constitucional.

Sin ir más lejos, el 22 de febrero de 2006, en el transcurso de una sesión de control al Gobierno, el Presidente del Gobierno español, Sr. Rodríguez Zapatero, señalaba en sede parlamentaria que "el derecho de autodeterminación no es un derecho democrático incluido en los sistemas politicos constitucionales contemporáneos”. Casi simultáneamente, el Gobierno Vasco, a través de un comunicado oficial, expresaba, en la misma línea que el Preámbulo del Plan Ibarretxe, que tal derecho era "un derecho humano reconocido internacionalmente a los pueblos por el Pacto Internacional de Derechos Civiles y Politicos y por el Pacto Internacional de Derechos Económicos, Sociales y Culturales. Por lo tanto, un derecho innegociable e irrenunciable".

El punto de partida de esta pretensión es la naturaleza que el Derecho Internacional atribuye a la autodeterminación de los pueblos. En concreto, el Pacto Internacional de Derechos Civiles y Políticos y el Pacto Internacional de Derechos Económicos, Sociales y Culturales, aprobados ambos en el seno de las Naciones Unidas, en Nueva York, el 19 de diciembre de 1966 y ratificados por España el 13 de abril de 1977, atribuyen a la autodeterminación la condición de un auténtico derecho humano.

El segundo paso consiste en afirmar que porque la autodeterminación es reconocida internacionalmente como un derecho humano, en nuestro ordenamiento constitucional, y en concreto merced al articulo $10.2 \mathrm{CE}$, el ius secessionis puede ser ejercido en cualquier momento y de inmediato. El punto débil de esta argumentación resulta claramente visible: que la autodeterminación sea, en el plano internacional, un derecho humano no quiere decir que, necesariamente, tenga que ser, en el plano interno, un derecho fundamental. Porque lo que el artículo 10. 2 CE hace, -al ordenar que las normas constitucionales declarativas de derechos fundamentales sean interpretadas "de conformidad con la Declaración Universal de los Derechos Humanos y los tratados y acuerdos internacionales sobre las mismas materias ratificados por España"- es establecer un criterio hermeneútico pero su función termina ahi. Esto es, el artículo 10. 2 no sirve para ampliar la tabla de derechos fundamentales establecida por el Constituyente. Su efecto se limita a establecer la obligación de que los derechos fundamentales constitucionalmente reconocidos se interpreten según las normas internacionales de Derechos Humanos. 
Para decirlo con mayor claridad y contundencia, para que una norma constitucional declarativa de derechos fundamentales pueda ser interpretada, por imperativo del articulo $10.2 \mathrm{CE}$, de conformidad con los Tratados de Derechos Humanos, es preciso que dicha norma exista. $\mathrm{Y}$ una norma que reconozca el derecho de autodeterminación como ius secessionis no solo no existe sino que fue rechazada expresamente por el Constituyente. Por ello -y dejando a un lado la errónea comprensión del significado del mencionado derecho, como hemos tratado de exponer anteriormente- resulta jurídicamente insostenible, tratar de oponer al Estado un derecho humano como el ius secessionis, que no solo no fue recogido en el Texto Constitucional como derecho fundamental sino que fue objeto del rechazo expreso por parte del constituyente de 1977-78.

\section{DERECHO DE AUTODETERMINACIÓN Y FACTICIDAD}

La dificultad (que no imposibilidad) de encajar sus pretensiones en el ordenamiento juridico explica (aunque no justifica) que las propuestas soberanistas se sitúen, no ya al margen, sino claramente en contra del derecho Constitucional interno y del Derecho Internacional Público.

Así las cosas, alentado por algunos teóricos de "la fuerza normativa de los hechos" y por un contexto internacional favorable a la fragmentación de los Estados (Serbia), el lehendakari Ibarretxe prescinde de las normas y apela a los hechos. De este modo, provoca una grave fractura en la sociedad vasca que podria derivar en un conflicto civil, y lo que es más grave, colocándose no solo al margen sino en contra de la legalidad vigente, destruye -conscientemente o no- los fundamentos de su propia legitimidad.

La posibilidad de deducir el derecho de secesión de la pura facticidad ha sido defendida por Miguel Herrero y Rodriguez de Miñon. El insigne Letrado del Consejo de Estado y miembro de la Ponencia Constitucional sostiene que aunque resultara imposible fundamentar el derecho de autodeterminación en el Derecho Constitucional vigente, siempre cabría la posibilidad de basar el ejercicio de aquél en la mera realidad, esto es en los hechos. "Si una consulta democrática hecha en condiciones de paz y libertad, ya se tratase de un referéndum o de unas elecciones autonómicas, arrojase un resultado claro a favor del derecho de autodeterminación, bien porque esa fuera la pregunta consultada o el programa mayoritariamente votado, el derecho de autodeterminación surgiria de la fuerza normativa de los hechos" ${ }^{13}$. Fácilmente se comprende que en el discurso del lehendakari del pasado 28 de septiembre se ha prescindido por completo de la exigencia de que la consulta se haga "en condiciones de paz y libertad", esto es sin la coac-

13 Herrero de Miñon, Miguel. "Encuesta sobre el Derecho de Autodeterminación”, Teoria y Realidad Constitucional, núm. 10-11, 2003. p. 105. 
ción terrorista. Pero es que, incluso si tales condiciones se cumplieran, desde una perspectiva democrática dicha tesis debe ser rechazada ${ }^{14}$.

Analicemos por separado cada uno de los supuestos a los que se refiere el autor.

a) En primer lugar, la celebración de un referéndum que arrojase un resultado claro a favor del reconocimiento del derecho que nos ocupa. En mi modesta opinión, una cosa es reconocer la fuerza normativa de los hechos sobre la que teorizara Jellinek, $y$, otra muy distinta, deducir de una violación flagrante del Texto Constitucional un hipotético ius secessionis a favor de determinadas Comunidades Autónomas. Y ello por la sencilla razón de que la convocatoria y celebración de una consulta o referendum sobre el derecho de autodeterminación por parte de un Gobierno Autonómico nunca podría ser entendido como un acto de soberania sino como una infracción manifiesta y grave del ordenamiento jurídico infracción doble: por un lado, del orden competencial que resulta del bloque de la constitucionalidad en la medida en que la competencia para convocar referendos es exclusiva del Estado; y, por otro lado, por pretender ejercer un derecho expresamente excluido por el constituyente: el de autodeterminación bien sea tendente a la secesión o a la creación de un Estado libre asociado. Infracción que, por elementales exigencias de la seguridad juridica, exigiria por parte del Estado una respuesta contundente. Y que, probablemente, requeriria poner en marcha el procedimiento previsto en el articulo 155 de la Constitución ${ }^{15}$. No hay supuesto más claro de "atentado al interés general de España" que el hecho de que una Comunidad Autónoma inicie el camino de la secesión.

b) Por lo que se refiere a la celebración de unas elecciones autonómicas que otorgaran una mayoría clara a fuerzas politicas defensoras del nacionalismo soberanista conviene recordar lo siguiente. Las elecciones, sean generales o autonómicas, tienen como finalidad que los ciudadanos participen en la composición de los órganos que han de conformar la voluntad del Estado o de la Comunidad Autónoma. En situaciones de normalidad constitucional, no pueden configurarse, de ninguna manera, como un plebiscito relativo a la continuidad o a la disolución del pacto social. El resultado de las elecciones determinará quien va a ocupar las posiciones de Gobierno y de oposición, respectivamente. Pero lo que me importa subrayar es que el Parlamento y el Gobierno surgidos de los comicios necesariamente habrán de configurarse como

14 Rutpérez, Javier (2003). "Proceso Constituyente, Soberania..." Op. cit. p. 365-383.

15 Art. 155 CE: "1.Si una Comunidad Autónoma no cumpliere las obligaciones que la Constitución u otras leyes le impongan, o actuare de forma que atente gravemente al interés general de España, el Gobierno, previo requerimiento al Presidente de la Comunidad Autónoma y, en el caso de no ser atendido, con la aprobación por mayoria absoluta del Senado, podrá adoptar las medidas necesarias para obligar a aquélla al cumplimiento forzoso de dichas obligaciones o para la protección del mencionado interés general. 2. Para la ejecución de las medidas previstas en el apartado anterior, el Gobierno podrá dar instrucciones a todas las autoridades de las Comunidades Autónomas". 
poderes constituidos del Estado, y sometidos por ello a la Constitución. Con independencia de los programas políticos defendidos, ningún partido está legitimado en el seno del Estado Constitucional para llevar a cabo actos revolucionarios.

Los defensores de la facticidad aluden también -con escasa oportunidad y fundamento- al ya clásico dictamen del Tribunal Supremo de Canadá de 20 de agosto de 1998. Pero se trata de una resolución judicial que en modo alguno legitima el ius secessionis unilateralmente ejercido, sino que, por el contrario, lo rechaza expresamente. Aunque el análisis del tema en el contexto del ordenamiento canadiense desbordaría los límites marcados a este ensayo, baste destacar que la tesis implicita en el dictamen citado coincide con la nuestra. El Tribunal Supremo de Canadá, enfrentado a la cuestión hipotética del derecho a la secesión de Quebec afirmó con claridad y contundencia que en el ordenamiento constitucional canadiense no existe ningún derecho de autodeterminación, pero después ha destacado la relevancia que tendria una voluntad politica secesionista afirmada de forma clara y mayoritaria. Sin entrar a valorar ahora que se entenderia por voluntad clara y mayoritaria -que, en todo caso dista mucho de la mitad más uno lo que importa es determinar cuáles son los efectos o consecuencias que el Tribunal Supremo de Canadá atribuye a la expresión de esa voluntad. En modo alguno se considera que por la fuerza normativa de los hechos esa voluntad sea un titulo de legitimación de la secesión unilateral de Québec ${ }^{16}$. Por el contrario, únicamente produce una obligación constitucional de entablar negociaciones de buena fe tanto para quien expresa la voluntad secesionista (Quebec) como para las demás provincias y el Gobierno federal.

Finalmente, y operando también en el plano de la facticidad y no de las normas, el profesor Vernet i Llovet, intenta fundamentar la vigencia del derecho de autodeterminación como derecho de secesión en la experiencia del surgimiento de nuevos Estados por fragmentación de los anteriormente existentes. Y es que, efectivamente, las fronteras europeas del Este reabrieron todas las modalidades teóricas sobre la teoria internacional de la sucesión de Ėstados (unificación, separación y disolución), sin que se aplicaran de forma uniforme las prescripciones y los procedimientos internacionales previstos en la Carta de las N̦aciones Unidas. Pero, a pesar de ello, no podemos compartir su conclusión: "Así, una vez han aparecido nuevas realidades estatales y éstas son reconocidas por otros Estados, el Derecho Internacional reconduce el proceso de formación de Estados nuevos, pero no puede impedirlo. El ordenamiento juridico internacional, pues, no prohibe el derecho de secesión, éste se dará como una situación de he. cho ante la cual el reconocimiento internacional se ampara en el principio de efectividad" ${ }^{17}$. La

16 Pérez Tremps, Pablo (2004). El marco (a)constitucional del debate sobre la secesión de Quebec. Barcelona: Fundación Carles Pi i Suñer. p. 32. Bilbao Ubillos, Juan Maria (1999). "La secesión de Quebec", Cuadernos de Alzate, núm. 21, 1999. pp. 83 y ss. Chacón, Carmen y Ruiz Robledo, Agustin (1999). El dictamen sobre la secesión de Quebec: un comentario, Barcelona: Fundación Carles Pi i Suñer.

17 Vernet Y LLovet, Jaume. "Encuesta sobre el Derecho de Autodeterminación", Teoria y Realidad Constitucional, núm. 10-11, 2003. p. 53. 
razón de nuestra discrepancia es que apelando en última instancia al principio de efectividad está renunciando a cualquier intento de justificación racional normativa de la secesión. En la medida en que no necesitan cobertura juridica internacional, los procesos secesionistas se fomentan, la inestabilidad internacional aumenta y se sientan las bases para destruir cualquier atisbo de orden mundial. Y esto es algo que con un ejemplo se comprende: si por la via de los hechos Kosovo se independiza de Serbia ¿por qué razón, los serbios de Kosovo no van a poder independizarse del nuevo Estado de Kosovo? Y así sucesivamente hasta el caos total.

Ahora bien, la razón principal y última por la que rechazamos esta tesis -la de la facticidad-es la siguiente: admitir que el poder normativo de lo fáctico se imponga a la Constitución supone aceptar la quiebra de la democracia. Si los hechos acaban prevaleciendo sobre la Constitución, no solo tendremos que certificar la defunción de España sino también la de la libertad. El principio que el genio juridico de Cicerón incorporó a la cultura política, legum servi summus ut liberi esse possummus (somos esclavos de las leyes para poder ser libres) y que Montesquieu introdujo en su concepción de la libertad política ("la libertad consiste en hacer lo que las leyes permiten porque si pudiéramos hacer lo que prohíben todos tendrian ese poder y ya no habria libertad"), despliega en este campo todo su significado.

\section{DERECHO DE AUTODETERMINACIÓN Y NUEVO PROCESO CONSTITUYENTE}

Si el derecho de autodeterminación como derecho de secesión no tiene encaje en nuestro ordenamiento constitucional, no puede -desde una perspectiva democrática- ser deducido de los hechos, y en la medida en que su reconocimiento afecta a la fórmula politica de la Constitución, al núcleo que debe permanecer inmune al poder de revisión (la soberanía indivisible del Pueblo español)-, tampoco puede ser introducido mediante una reforma constitucional, resulta obligado subrayar las vías democráticas que el lehendakari Ibarretxe y los defensores del soberanismo secesionista podrian utilizar para la satisfacción de sus propósitos.

Nada de lo que he expuesto debe interpretarse en el sentido de que se niegue la legitimidad ideológica y politica de aquellas propuestas tendentes a reconocer el ius secessionis. Lo que en este ensayo he rechazado rotundamente es únicamente los procedimientos contrarios al Derecho y a la Democracia mediante los que tal objetivo se pretende alcanzar. Porque está claro que, desde un punto de vista democrático, debemos tener presente las observaciones de Rousseau sobre la posibilidad de sustituir un pacto social por otro, aunque eso si, debiendo observar los mismos requisitos y formalidades que se exigieron para la celebración del primero: "Va contra la naturaleza del cuerpo político darse leyes que luego no pueda revocar, pero no va contra la naturaleza ni contra la razón que no pueda revocarlas más que con la solemnidad puesta en práctica al establecerlas" ${ }^{18}$.

18 Rousseau, J.J. Consideraciones sobre el Gobiemo de Polonia y su proyecto de reforma (1775). 
Rousseau se referia asi no solo a la posibilidad de realizar cambios en la Constitución, sino también cambios de Constitución. Efectivamente, todo pueblo conserva el derecho imprescriptible de variar el pacto social, y con ello de dotarse de una nueva Constitución. Por ello, a los que aspiran a la disolución del pacto social vigente hay que reconocerles siempre el derecho a solicitar la apertura de un nuevo proceso constituyente (lo que se hizo en Checoeslovaquia), lo que, llegado el caso, no podria hacerse de forma unilateral, sino que deberia ser aceptado por la mayoria del cuerpo electoral de España como conjunto unitario ${ }^{19}$. Porque fue el pueblo español en su conjunto el que aprobó la vigente Constitución habrá de ser también el pueblo español en su conjunto y no una fracción minoritaria de este el que deba decidir el cambio de aquella por otra. Por tanto, lo que deben hacer los nacionalistas vascos es convencer al resto de los españoles de que su alternativa es la mejor y más provechosa para todos.

Como nos advertia el insigne historiador y jurista, Tomás y Valiente: "España es una realidad histórica, un producto de la historia, construida por los hombres que sucesivamente han vivido en su actual territorio" ${ }^{\prime 2}$. Y precisamente porque se trata de una realidad histórica, España, de la misma forma que tuvo un origen, inexorablemente, tendrá un final. Ahora bien, lo que desde la más elemental lógica jurídica y politica democrática no puede ser aceptado es que ese final sea decretado unilateralmente por una minoria. Ninguna fracción del pueblo del Estado tiene derecho a decidir en nombre de la totalidad del pueblo. Lo que a todos concierne por todos debe ser decidido.

Finalmente y antes de analizar el caso concreto de Kosovo (por su trascendencia para la seguridad europea), creo necesario incluir en este capitulo por su importancia teórica, el examen de la relación existente entre el Estado Federal y el Derecho de Autodeterminación.

\section{ESTADO FEDERAL Y DERECHO DE AUTODETERMINACIÓN}

Para algunos no es necesario que el derecho de autodeterminación de las colectividades miembros de una Federación -entendido como derecho de secesión- sea reconocido expresamente por el Poder Constituyente en el Texto de la Constitución federal, y no lo es porque dicho derecho sería inherente a esa forma de Estado ${ }^{21}$.

19 Rutperrez, Javier (2003) "Proceso Constituyente, Soberania". Op. Cit., pp. 380 y ss.

20 TOMás Y VALIENTE, Francisco (1993) "Raices y paradojas de una conciencia colectiva" En: Escritos sobre y desde el Tribunal Constitucional, Madrid: CEPC. p. 193.

21 Esta es la tesis, por ejemplo, del profesor Caamaño Dominguez. Según el Catedrático de la Universidad de Valencia, cuando el poder constituyente se ejerce "para constituir un Estado demoliberal y politicamente descentralizado, el derecho de autodeterminación, no el de cada individuo sino el de las minorias nacionales constitucionalmente reconocidas, no se agota en el momento constituyente, aunque nada se diga al respecto en la literalidad del texto constitucional. Toda federación tiene que aprender a vivir bajo la espada de Damocles de una posible secesión". Caamaño Domínguez, Fran. "Encuesta". Op. Cit., p. 15. 
En los debates constituyentes, por ejemplo, el profesor Fraga Iribarne, se opuso al reconocimiento del derecho de autodeterminación alegando que eso sería propio de un Estado Federal, fórmula esta objeto de un profundo rechazo por parte de Alianza Popular ${ }^{22}$. A contrario sensu cabría entender, por tanto, que si España fuera un Estado Federal, no habria ningún inconveniente en admitir el derecho de secesión.

Esta tesis dista mucho de ser pacifica doctrinalmente, $y$, en definitiva, su admisión o rechazo va a depender de qué es lo que entendamos por Estado Federal. Carl Schmitt lo planteó en los siguientes términos: si el Estado Federal "según su esencia, debe ser permanente, el ingreso en la Federación debe significar la renuncia permanente al derecho de secesión; pero si la Federación ha de ser al mismo tiempo pacto, y los Estados que la integran no deben perder su existencia política independiente, necesitan quedar los miembros de la Federación en situación de decidir por sí mismos sobre la eventual imposibilidad, aplicabilidad y cesabilidad de ese pacto, y éste es, precisamente, un derecho de secesión" ${ }^{23}$.

En este sentido baste con recordar que aquellos autores (Calhoun y Von Seydel ${ }^{24}$ ) para los que la soberanía reside en los Estados miembros y no en la Federación, la secesión será siempre un derecho inherente a las colectividades miembros. Ahora bien, esta doctrina es minoritaria. Y ello porque para la mayoría de los contractualistas como recuerda el profesor Ruipérez, la "entrada en vigor de la Constitución federal conlleva el cambio de status de los Estados contratantes, los cuales, pierden su condición de soberanos, sujetos de Derecho Internacional, para convertirse en colectividades miembros del Estado Federal, único soberano e integrante de la sociedad internacional" 25 .

Sin entrar en más precisiones y detalles es preciso afirmar que las tesis de Calhoun y Von Seydel según las cuáles porque los Estados miembros siguen siendo soberanos conservan siempre el derecho de abandonar la Federación no es que no sirvan para explicar la naturaleza del Estado Federal sino que lo que hacen es negar su misma existencia y realidad. Si el Pacto federal que da lugar a la Constitución federal no produce el efecto de trasladar la soberania de los pueblos de las colectividades miembros al Pueblo federal, el resultado al que llegamos no es otro que a una Confederación de Estados. Porque efectivamente en la Confederación como fruto de un Tratado Internacional suscrito entre Estados y no de una Constitución emanada de un Pueblo constituyente, los Estados miembros conservan la cualidad de soberanos.

22 Tal fue el tenor de su intervención para rechazar las enmiendas de Euskadiko Esquerra. Diario de Sesiones del Congreso de los Diputados, núm. 113 (19 de julio de 1978).

23 Schmitr, Carl (1927) Teoria de la Constitución, (1992). Madrid: Alianza Editorial. p. 356.

24 Schmitt, Carl (1927) Op. Cit., pp. 354-355. Carré de Malberg, R. (1920-22):Teoria General del Estado, $2^{2}$ edición, México, (1998) FCE-UNAM. pp. 136 y ss.

25 Ruperez, Javier (1995) “Constitución y autodeterminación” Op. Cit., pp. 81.82. 
Así lo advirtió, entre otros, Carré de Malberg: "Admitir que la Unión de Estados conocida con el nombre de Estado federal no da origen, de ningún modo, a un Estado superior, sino que viene a ser únicamente una sociedad contractual entre Estados que siguen siendo soberanos, es decir una mera confederación (...) es la negación del Estado Federal” ${ }^{26}$.

En todo caso, y al margen de la aludida confusión entre Confederación de Estados y Estado Federal, la controvertida cuestión de la cosoberanía fue resuelta por la Historia. La guerra de secesión norteamericana zanjó el debate en el sentido de rechazar la soberanía de los Estados miembros. Se confirmó asi que sobre un mismo territorio no pueden existir dos soberanos. La cosoberanía era y es una hipótesis contraria a la razón y a la lógica más elemental. Con meridiana claridad y acierto lo percibio Heller:

Es posible que dos ejércitos luchen por establecer sus respectivas soberanias sobre un territorio determinado, en cuyo caso, el jurista tendrá que aceptar la existencia de una lucha por la soberania, que durará hasta la terminación de la guerra. Es en cambio imposible aceptar que sobre un mismo territorio existan dos unidades decisorias supremas; su existencia significaria la destrucción de la unidad del Estado y su consecuencia sería el estallido de la guerra civil ${ }^{27}$.

Todo lo anterior explica que para la doctrina mayoritaria, esto es, para los grandes teóricos del Estado (Jellinek, Carré de Malberg, Heller) la existencia del derecho de autodeterminación como derecho de secesión lejos de ser un elemento esencial del Estado Federal es contemplado como el criterio diferenciador de la Confederación y el Estado Federal. En tanto que la primera es una unión de derecho internacional basada en un Tratado suscrito por Estados soberanos, estos pueden abandonarla cuando consideren que las circunstancias han cambiado y que su pertenencia a la misma ya no les resulta conveniente; en el Estado Federal, por el contrario, al tratarse de un verdadero Estado, tal posibilidad de secesión as absolutamente inadmisible.

Establecido lo anterior, y para que esta exposición no quede incompleta, es preciso referirse también a la tesis de Kelsen en la medida en que se trata de uno de los grandes teóricos del Estado y uno de los más importantes juristas demócratas del siglo XX. Y es preciso hacerlo porque el creador de la Escuela de Viena discrepa en cierta medida de las afirmaciones precedentes. En todo caso, como veremos, se trata de una tesis que prácticamente ha carecido de proyección en la realidad y en la historia.

Carré de Malberg, R. (1920-22) Teoria Genetal del Estado... Op. Cit., pp. 135-136.

Heller, Hermann (1927) La soberania. Contribución a la teoria del derecho estatal y del derecho internacional, México, D.F. (1995) Fondo de Cultura Económica-UNAM, 2ª edición, p. 214. Igualmente, Carré de Malberg, R. (1920-22). Teoria General del Estado... Op. Cit., p. 143. Jellinek, George (1911): Teoria General del Estado, Granada (2000), Comares. p. 488. Rousseau, J.J.: Contrato social... Op. Cit., pp. 58-60. 
Si hasta ahora habíamos visto que el reconocimiento del derecho de autodeterminación era incompatible con la existencia del Estado Federal como auténtico Estado Constitucional basado en el Poder Constituyente del Pueblo federal, Kelsen sostendrá que hay que admitir la hipótesis de que dicho reconocimiento sea posible: "Es posible que tal derecho (el ius secessionis) sea concedido expresamente a los miembros por la constitución de la unión; en ese caso, establécese el fundamento jurídico de la terminación de la misma. Pero se comprende fácilmente que ese derecho de abandonar la unión no puede concederse sin limitaciones (...) Sólo con ciertas condiciones puede concederse, pues, el derecho de retirarse de la unión" ${ }^{28}$. Ahora bien, dicho esto, concluye con claridad y contundencia que "si no es concedido bajo ninguna condición, no hay ningún fundamento de Derecho positivo para afirmar su existencia" 29 . En otras palabras, Kelsen admite que el Poder Constituyente al establecer la Constitución Federal puede reconocer expresamente el derecho de autodeterminación de las colectividades miembros, y ello además con ciertas condiciones, pero advierte, igualmente, que a falta de ese reconocimiento expreso, dicho derecho carece de cualquier fundamento.

A esta tesis se adhiere en la doctrina española el profesor Ruipérez: "Para que la autodeterminación como secesión sea posible en el ámbito del Estado Federal, es necesario que su posibilidad haya sido expresamente prevista por el Poder Constituyente que aprobó y sancionó la Constitución federal" ${ }^{30}$.

Se trata sin duda alguna de una posición coherente con la doctrina democrática del Poder Constituyente como poder absoluto e ilimitado en el contenido de su voluntad. Ahora bien, dicho esto, no puede sorprendernos el hecho de que el constitucionalismo comparado no nos proporcione ni un solo caso en que el constituyente federal haya obrado asi. Y ello porque los supuestos que tradicionalmente se han ofrecido para ilustrar esta teoría, las constituciones so-

28 Kelsen, Hans (1925) Teoria General del Estado, Comares (2002), Granada. pp. 373-378 con las que concluye el libro II.La validez del orden estatal. La cita es de la p. 376.

29 Ibidem.

30 Rulpérez, Javier (1995) "Constitución y autodeterminación..." Op. cit., p. 89. Naturalmente esto exige plantearnos nuevamente la diferencia que en tal caso existiria entre la Confederación de Estados y cl Estado Federal. La diferencia según el autor citado sigue existiendo: "Por una parte, ambas formas de agrupación se distinguen en cuanto al origen de este derecho (ius secessionis). En la Confederación de Estados el ius secessionis es una facultad con la que cuentan los Estados por el mero hecho de ser tales y haberse integrado en la Unión. Por el contrario, en el Estado Federal, este derecho tan sólo existirá cuando haya sido aceptado por el Constituyente (...) Por otra parte, también son diferentes las condiciones que en uno y otro caso se requieren para poder ejercitar el derecho de secesión. En el caso de la Confederación, la posibilidad de que alguno o algunos de los miembros se separen de la Unión se encuentra justificada por la cláusula rebus sic stantibus(...)En el caso del Estado Federal, la secesión nunca podrả ser entendida como una potestad ilimitada”. pp. 90-91. 
viéticas ${ }^{31}$ y la de la extinta República Yugoeslava, no eran, en puridad, constituciones racionales normativas, o dicho con otras palabras, no eran constituciones democráticas.

Al fin y al cabo, y aun admitiendo, con Kelsen, que el Constituyente puede reconocer el derecho de secesión de las colectividades miembros ${ }^{32}$, preciso es afirmar que dicha opción resulta contradictoria con uno de los fines esenciales del Estado que es su conservación y permanencia. Dicho con otras palabras, admitir la secesión es constitucionalizar la posibilidad de destrucción del Estado como posibilidad jurídica y no meramente fáctica o revolucionaria. Esto es lo que explica que ninguna Constitución democrática haya reconocido nunca este derecho. Y la nuestra, como veremos, no ha sido una excepción.

Resumiendo todo lo anterior podemos afirmar que en un Estado Federal o políticamente descentralizado, la legitimidad del derecho de secesión solo puede fundarse en su reconocimiento expreso por parte del Poder Constituyente que establece y sanciona la Constitución. En el caso de España, las enmiendas que en sede constituyente se presentaron a favor del reconocimiento del ius secessionis fueron todas rechazadas de forma rotunda y contundente. El no reconocimiento constitucional de la autodeterminación como derecho de secesión fue el inequívoco resultado de una decisión plenamente consciente.

\section{LA AUTODETERMINACIÓN DE KOSOVO Y LAS NUEVAS FRONTERAS EN EUROPA}

Todo lo anteriormente expuesto es aplicable a cualquier pretensión secesionista que afecte a la integridad de un Estado. En el momento presente, el caso de Kosovo se presenta como un

31 Respecto a la antigua Unión Soviética hay que advertir que a pesar de que el artículo 72 de la Constitución soviética de 7 de octubre de 1977 disponía: "A cada República federada se le conserva el derecho a separarse libremente de la URSS", el ius secessionis no era una facultad ilimitada cuyo ejercicio dependiera exclusivamente de la voluntad de las Repúblicas federadas. Antes al contrario se trataba de un derecho subordinado a su aceptación por el Estado Federal Soviético. Ello se deduce con claridad del artículo 73 del Texto constitucional citado, según el cual, correspondía a los órganos superiores del poder federal la competencia para "determinar la frontera estatal de la URSS y ratificar las modificaciones de fronteras entre otras Repúblicas federadas" así como "decidir otras cuestiones de relevancia para toda la federación". Y recordamos esto, no obstante, desde la convicción de que como ha puesto de manifiesto el profesor La Pergola, (y como lo hicieron antes M. Mouskheli, K.C. Wheare, C. J. Friedrich o K. Loewenstein) la URSS no era en puridad un Estado Federal por no ser un Estado constitucional democrático. La Pérgola, Antonio (1990): Los nuevos senderos del federalismo. Madrid: CEPC. pp. 138-139. En todo caso, las anteriores circunstancias son las que explican que a pesar de las enormes diferencias jurídicas, políticas, históricas y sociales que separan a la Constitución de los EE. UU y a la última Constitución nominal soviética, y a los 150 años que median entre la guerra de secesión norteamericana y la perestroika soviética, la respuesta inmediata del Presidente Lincoln frente a los Estados del Sur y la de Gorbachov frente a las Repúblicas bálticas fueran idénticas.

32 Para Kelsen el ejercicio del ius secessionis deja de ser un acto de soberanía (que es lo que supone en la Confederación) para convertirse en una facultad constitucional. 
supuesto en el que la independencia del mismo parece haber tenido éxito. Y ello a pesar de que dicha independencia sea contraria tanto al Derecho Constitucional interno serbio como al Derecho Internacional

Aunque se diga que el caso de Kosovo es distinto, el problema jurídico-politico subyacente es, se quiera o no reconocer así, idéntico. Dejando a un lado la propuesta del Gobierno de los Estados Unidos de aceptar la declaración unilateral de independencia, que es la que lamentablemente ha prosperado, lo que nos ha colocado, una vez más, en el plano de la pura facticidad, el futuro de la actual provincia Serbia podia haberse diluciado mediante un pronunciamiento del Consejo de Seguridad de las Naciones Unidas. Situado el problema en el contexto normativo e institucional de las Naciones Unidas, el caso Kosovo puede y debe examinado desde una perspectiva jurídica. Tal es el propósito de este último epigrafe.

El Consejo de Seguridad de las Naciones Unidas debió haberse pronunciado sobre el denominado Plan Ahtissari que preveía la independencia de la provincia serbia de Kosovo en contra de la voluntad del Estado serbio. No creo que sea exagerado afirmar que la votación del Consejo sobre este asunto habria resultado una votación decisiva no solo para Kosovo y para Serbia, los directamente involucrados en el asunto, sino también para el futuro de Europa y del mundo. Si el Consejo hubiera decretado la independencia de Kosovo en contra de la voluntad de Serbia habría adoptado una decisión que desde una perspectiva jurídica solo puede ser calificada de manifiestamente contraria al Derecho Internacional vigente, y desde una perspectiva política, como una irresponsable invitación a la modificación de las fronteras existentes.

Por ello, y eso es lo que quiero subrayar, el Consejo no podria haber declarado en ningún caso esa independencia. La hipótesis contraria se apoya en una determinada comprensión del Consejo como un órgano que todo lo puede, y no sujeto, por tanto, à límite juridico material alguno. El único limite a su actuación sería formal o procedimental: la exigencia de una determinada mayoría cualificada.

En similares (y reduccionistas) términos se planteó en nuestro pais, hace tres años, el debate sobre la retirada de las tropas de Irak. Asi, se dijo entonces y se repite hoy, que la guerra de Irak fue ilegal porque no contó con el aval de la ONU, lo cual significa, a sensu contrario, que si el Consejo de Seguridad hubiese autorizado un ataque contra Irak, la guerra hubiera sido legal y legítima. Fácilmente se comprende que en esa tesis subyace la idea de que el Consejo de Seguridad, en la medida en que encarna la legitimidad internacional, confiere esa legitimidad a cualquier actuación que apruebe. Esa tesis resulta juridicamente insostenible

El Consejo de Seguridad, por su propia naturaleza y configuración como un órgano intergubernamental donde cada uno de sus miembros actúa en defensa, principalmente, de los 
intereses del Estado al que representa, no puede encarnar la legitimidad internacional. Dicha legitimidad reside en la propia Carta de las Naciones Unidas. Asi la carta contiene los principios y valores, juridicos y politicos, integrantes de dicha legitimidad, para cuya realización crea una serie de órganos a los que atribuye determinadas funciones. Entre esos órganos, el Consejo de Seguridad se configura como la instancia decisoria suprema. Pero lo que no se puede olvidar es que todos los órganos, incluido el propio Consejo, están sometidos o subordinados en su actuación a lo dispuesto por la Carta. Para decirlo con mayor claridad, el Consejo no podría aprobar válidamente una resolución que contradijera los principios establecidos en el Tratado fundacional de la ONU. El problema reside en que si lo hiciera no existe ninguna instancia que pudiera anularla. Y este es el punto débil de toda la arquitectura del sistema de Naciones Unidas. El edificio legal de la ONU, solo podrá ser pensado "constitucionalmente" en términos de legitimidad cuando se atribuya a un órgano internacional el control de las resoluciones del Consejo de Seguridad. Ahora bien, el que dicho control en la actualidad no exista no permite concluir sin más que todas las decisiones del Consejo resulten per se lícitas.

Si el Consejo aprueba una resolución que persigue avalar un ataque armado contra un pais que no representa una amenaza para la paz y la seguridad del mundo (como se planteaba en el debate sobre Irak) o que pretende amparar un atentado contra la integridad territorial de un Estado, como es el caso que nos ocupa, es preciso denunciar que dichas resoluciones contradirian abiertamente principios fundamentales de la Carta como son la prohibición de la agresión o la garantía de la integridad territorial de los Estados. Y por contradecir esos principios, dichas resoluciones, serían siempre ilegales e ilegitimas. En el Derecho Internacional, la legitimidad se identifica con los principios y valores de la Carta de San Francisco, no con las resoluciones del Consejo de Seguridad. El Consejo no puede legitimar la violación de la Carta.

Si lo anterior tiene algún fundamento, la conclusión que de ello se extrae resulta clara: si el Consejo de Seguridad decretara la independencia de Kosovo, jurídicamente estaría atentando contra los presupuestos de su propia legitimidad. El Consejo está subordinado a la Carta y según esta la secesión -como hemos expuesto anteriormente- solo se justifica para pueblos sometidos a dominación colonial o que viven bajo Estados no democráticos. Ninguno de esos requisitos se da en el caso que nos ocupa.

\section{CONCLUSIONES}

El reconocimiento de la independencia de Kosovo constituye un peligroso precedente de alteración de las fronteras por la fuerza. El nuevo Estado de Kosovo es el fruto maduro de los bombardeos de la OTAN sobre Belgrado. En esto y no en otro lugar, reside la peculiaridad del caso Kosovo. Pero haciendo abstracción de que el nuevo Estado surge como consecuencia de una acción militar, su nacimiento será considerado como un precedente político en virtud del 
cual se sostendrá que las fronteras existentes entre los Estados europeos pueden ser modificadas, y que es posible la creación de nuevos Estados por fragmentación de otros, sin contar con la voluntad de estos últimos.

En la Europa Central y del Este se han creado unos 13000 kilometros de fronteras nuevas desde 1989. Los resultados, nos recuerda Anthoni Giddens, no han dejado satisfechos a todos, ni mucho menos. Solo una pequeña proporción de los habitantes de Europa Occidental -entre los que se encontraría el lehendakari Ibarrtexe y sus seguidores- consideran "no definitivas" sus fronteras nacionales. En la Europa Central y del Este, sin embargo, es más de la mitad de la población la que así opina ${ }^{33}$. En este contexto, la autodeterminación entendida como secesión es hoy como ayer una bomba de relojería.

Que los Estados Unidos aprueben esta politica no puede causar sorpresa alguna. No en vano fue su Presidente Wilson quien, con su formulación del derecho de autodeterminación, sembró la semilla del caos en los Balcanes en los años veinte de la pasada centuria. Lo sorprendente es que las potencias europeas (incluida España que vive sometida a tensiones secesionistas como la que nos ocupa) transiten irresponsablemente por tan peligrosa senda ${ }^{34}$. Europa tiene una grave responsabilidad en la crisis balcánica. Europa puede y debe mediar para que el conflicto se resuelva respetando el Derecho Internacional vigente. Basta con hacer saber a ambas partes que su adhesión a la Unión Europea exige como requisito previo un acuerdo de convivencia política de naturaleza federal. Lo que carece de sentido es que Europa aliente la fragmentación de Serbia, exigiéndole como condición para su integración en la Unión Europea, su previa fragmentación en dos Estados diferentes. Y más asombroso resulta todavía que dicha fragmentación se justifique en términos de puro racismo, esto es, en la necesidad de construir un Estado de base étnica. ¿Aprobaría Europa que los serbios que viven en Kosovo construyeran después su propio Estado? El hecho de que este interrogante no carezca de sentido nos pone de manifiesto que la destrucción de los Estados existentes además de ser contraria al derecho internacional- no sirve para resolver los problemas de convivencia entre distintos pueblos dentro de un mismo Estado.

33 Gidoens, A. (2007) “El futuro de Europa”, Claqes de Razón Práctica, No. 175, setiembre de 2007. p. 5

34 En el momento de redactar estas lineas (4 de junio de 2008) el Gobierno de Rodriguez Zapatero continúa sín reconocer al nuevo Estado. A diferencia de otros gobiernos europeos, España mantiene su respeto por la legalidad y la legitimidad internacionales. 
